\title{
PENINGKATAN AKTIVITAS DAN HASIL BELAJAR IPA MELALUI KOOPERATIF TIPE TWO STAY TWO STRAY BAGI SISWA KELAS VII 1 SMP NEGERI 2 TOROH KABUPATEN GROBOGAN SEMESTER GENAP TAHUN 2015/2016
}

\author{
Yuni Rahmawati Haryono \\ SMP Negeri 2 Toroh \\ haryonoyunirahmawati@yahoo.com
}

\begin{abstract}
The purpose of this study was to determine how the increasing activity and Science learning outcomes through the cooperative type Two Stay Two Stray (TSTS) for students of classes VII I of SMP Negeri 2 Toroh Grobogan in the Academic Year 2015/2016. This research is a classroom action research with qualitative approach. Data analysis technique conducted is a qualitative descriptive. Descriptive analysis is used to describe the implementation model of learning science (biology) by the teachers and to calculate the percentage of the number of students who succeed in learning. Things that were analyzed were the activities of teachers and students in the learning process through the cooperative typeTwo Stay Two Stray (two live two guests) in a bid to improve the activity and student learning outcomes. Indicators of success in this research are student learning, mastery learning, as well as increased activity of students. Data collection methods used were observation and documentation. This study used two cycles. At each cycle through the stages of planning, implementation, observation, and reflection. There is an evaluation in each cycle, that is at the last meeting. Based on the results of classroom action research conducted in two cycles using cooperative learning type Two Stay Two Stray (two live two guests) we concluded that the findings in Cycle I and Cycle II is going on improving student learning outcomes, that is the average value of the class of 66 , 32 when the stage precycle be 75.82 in Cycle I, and 72.91 in the Cycle II. Type TSTS also able to improve students' mastery learning when compared with precycle stage. Mastery learning students of class VII precycle first phase was $41.2 \%$, increasing to $79.4 \%$ in the first cycle and 76.4\% in Cycle II. Based on the indicators of the success of this study, mastery learning cycle I was successful because of $\geq 75 \%$, that is $77.5 \%$. and the second cycle was successful because of $\geq 75 \%$, that is $79.4 \%$ and 76.4\%. Although from the first cycle to the second cycle a decline in the average value of the classroom and students' mastery learning, but learning science with type two stay two guests said successful because of an increase when compared to precycle stage. There is also the increasing activity of the students who turned out to give the effect of rising student learning outcomes.
\end{abstract}

Keywords: learning activities, learning outcomes, science, biology, cooperative, 


\begin{abstract}
ABSTRAK
Tujuan penelitian ini adalah untuk mengetahui bagaimanakah peningkatan aktivitas dan hasil belajar IPA melalui kooperatif tipe Two Stay Two Stray (TSTS) bagi siswa kelas VII I SMPNegeri 2 Toroh Kabupaten Grobogan pada Tahun Pelajaran 2015/2016. Penelitian ini merupakan penelitian tindakan kelas dengan menggunakan pendekatan kualitatif. Teknik analisis data dilakukan secara deskriptif kualitatif. Analisis deskriptif digunakan untuk mendeskripsikan implementasi model pembelajaran IPA (biologi) yang dilakukan guru dan untuk menghitung persentase jumlah siswa yang berhasil dalam pembelajaran tersebut. Hal-hal yang dianalisis adalah aktivitas guru dan siswa dalam proses pembelajaran melalui kooperatif tipe Two Stay Two Stray (dua tinggal dua tamu) sebagai upaya untuk meningkatkan aktivitas dan hasil belajar siswa. Indikator keberhasilan dalam penelitian ini adalah hasil belajar siswa, ketuntasan belajar, serta peningkatan aktivitas siswa. Metode pengumpulan data yang digunakan adalah observasi dan dokumentasi. Penelitian ini menggunakan dua siklus. Pada setiap siklus melalui tahapan perencanaan, pelaksanaan, observasi, dan refleksi. Pada setiap siklus dilakukan evaluasi, yaitu pada pertemuan yang terakhir. Berdasarkan hasil penelitian tindakan kelas yang dilakukan dengan dua siklus dengan menggunakan pembelajaran kooperatif tipe Two Stay Two Stray (dua tinggal dua tamu) diperoleh kesimpulan bahwa temuan pada Siklus I dan Siklus II adalah terjadi peningkatan hasil belajar siswa, yaitu nilai rata-rata kelas dari 66,32 saat tahap prasiklus menjadi 75,82 pada Siklus I, dan 72,91 pada Siklus II. Tipe TSTS juga mampu meningkatkan ketuntasan belajar siswa jika dibandingkan dengan tahap prasiklus. Ketuntasan belajar siswa kelas VII I pada tahap prasiklus adalah 41,2 \%, meningkat menjadi 79,4 \% pada Siklus I dan 76,4 \% pada Siklus II. Berdasarkan indikator keberhasilan penelitian ini, ketuntasan belajar Siklus I dikatakan berhasil karena $\geq 75 \%$ yaitu 77,5\%. maupun siklus II dikatakan berhasil karena $\geq 75 \%$ yaitu 79,4 \% dan 76,4 \%. Meskipun dari siklus I ke siklus II terjadi penurunan nilai rata-rata kelas maupun ketuntasan belajar belajar siswa, namun pembelajaran IPA dengan tipe dua tinggal dua tamu dikatakan berhasil karena terjadi peningkatan jika dibandingkan dengan tahap prasiklus. Terjadi pula peningkatan aktifitas siswa yang ternyata memberikan dampak kenaikan hasil belajar siswa.
\end{abstract}

Kata kunci: aktivitas belajar, hasil belajar, IPA, biologi, kooperatif, dua tinggal dua tamu

\title{
PENDAHULUAN
}

Pendidikan adalah usaha sadar yang dengan sengaja dirancangkan untuk mencapai tujuan yang telah ditetapkan. Pendidikan bertujuan untuk meningkatkan kualitas sumber daya manusia. Salah satu usaha untuk meningkatkan kualitas sumber daya manusia adalah melalui proses pembelajaran di sekolah. Guru merupakan komponen sumber daya manusia 
yang harus berkembang terus menerus sebagai usaha untuk meningkatkan kualitas sumber daya pendidikan. Pengembangan kualitas guru antara lain dengan cara mengembangkan pembelajaran. Pengembangan pembelajaran yang dilakukan guru sebagai upaya untuk meningkatkan kualitas peserta didik.

Siswa melakukan kegiatan belajar. Dalam proses belajar terjadi perubahan tingkah laku, akibat dari latihan atau pengalaman yang dialami oleh siswa. Tuntutan akan kemandirian dalam belajar sangat didambakan oleh berbagai pihak, karena kemandirian dapat secara otomatis mengantarkan kepada kedewasaan berpikir. Aktifitas siswa sekolah dasar harus sudah dilatih dan diarahkan kepada hal-hal yang dapat melatih mental dan fisik siswa tersebut. Belajar secara aktif dapat dilakukan dengan mengaktifkan fungsi interaksi individu dengan tugas sehari-hari sebagai seorang siswa. Pengelolaan proses belajar mengajar yang kondusif bagi perkembangan peserta didik atau siswa perlu direncanakan dengan sebaik-baiknya (Soedijarto, 1993:82).

SMP Negeri 2 Toroh merupakan Sekolah Standar Nasional yang memiliki 28 kelas, satu laboratorium bahasa, dua laboratorium IPA, satu ruang multimedia, 2 ruang laboratorium TIK, serta beberapa fasilitas lainnya. Penelitian ini dilakukan pada siswa kelas VII I yang berjumlah 34 siswa yang terdiri dari 15 siswa dan 19 siswi. Jumlah guru tersertifikasi sejumlah 39 orang dan 10 orang belum tersertifikasi.

Pendekatan belajar aktif untuk meningkatkan keaktifan siswa ada berbagai upaya dan pertimbangan bagi seorang guru. Guru harus juga aktif melakukan feed back terhadap kegiatan siswa. Dengan demikian melalui tahapan usaha untuk membangun pengetahuan dalam dirinya. Secara otomatis dalam proses belajar dengan meningkatkan aktifitas siswa, maka akan terjadi perubahan dan peningkatan suatu kemampuan, pengetahuan, dan ketrampilan siswa baik dari segi kognitif, psikomotorik, dan afektif.

Banyak model pembelajaran yang bermanfaat bagi siswa, khususnya bagi siwa berbakat di kelas biasa atau di kelas khusus dalam menumbuhkan kreativitas, dan melatih kerjasama siswa dalam memecahkan masalah. Pembelajaran akan berhasil jika seorang guru dapat memilih dengan tepat model pembelajaran yang sesuai dengan kondisi siswa dan karakteristik materi yang akan dibahas.

Keberhasilan pembelajaran IPA tidak lepas dari kemampuan guru dalam membelajarkan IPA di kelas. Pembelajaran IPA kebanyakan masih didominasi oleh penggunaaan metode ceramah yang kegiatannya berpusat pada guru Aktivitas siswa hanya mendengarkan guru dan mencatat hal-hal yang dianggap penting. Guru menjelaskan materi-materi IPA hanya sebatas produk dengan sedikit proses. Pembelajaran kooperatif dengan model Two Stay Two Stray (TSTS) atau model dua tinggal dua tamu merupakan salah satu model pembelajaran secara diskusi kelompok yang membuat siswa harus bekerja sama dengan siswa lain dalam satu kelompok maupun dengan kelompok lain. Dalam model ini terdapat empat siswa dalam satu kelompok yang terbagi menjadi dua bagian, yaitu dua siswa yang berperan sebagai tuan rumah dan dua orang yang berperan sebagai tamu. Setiap kelompok tidak hanya memiliki satu hasil diskusi, melainkan harus memiliki beberapa salinannya untuk dibagikan pada kelompok lain.

Berdasar hasil observasi pendahuluan dan quesioner di kelas VII I SMP Negeri 2 Toroh Kabupaten Grobogan diperoleh kesimpulan bahwa pembelajaran cenderung menggunakan metode ceramah, metode kooperatif/diskusi yang dilakukan sebelumnya terlalu banyak 
jumlah anggota kelompok - lebih dari 5 siswa - sehingga siswa cenderung bercerita sendiri, lebih dari 65\% siswa tidak aktif dalam kegiatan pembelajaran, sekitar 75\% siswa tidak berani mengungkapkan pendapatnya, 60\% siswa memiliki nilai di bawah KKM. Melihat kenyataan dalam pra kondisi ini, maka dilaksanakan penelitian tindakan kelas dengan judul "Peningkatan Aktivitas dan Hasil Belajar IPA melalui Kooperatif Tipe Two Stay Two Stray (TSTS) bagi Siswa Kelas VII I SMP Negeri 2 Toroh Kabupaten Grobogan pada Semester Genap Tahun Pelajaran 2015/2016".

Berdasarkan uraian tersebut diajukan hipotesis tindakan, model pembelajaran Two Stay Two Stray (dua tinggal dua tamu) dapat meningkatkan penguasaan konsep IPA (Biologi). Penelitian ini bertujuan untuk mengetahui bagaimanakah peningkatan aktivitas dan hasil belajar IPA melalui kooperatif tipe Two Stay Two Stray (TSTS) bagi Siswa Kelas VII I SMP Negeri 2 Toroh Kabupaten Grobogan pada semester genap tahun pelajaran 2015/2016.

\section{METODE}

Penelitian ini merupakan penelitian eksperimen, dengan Teknik Pelaksanaan Penelitian Tindakan Kelas (Classroom Action Research), sebagaimana dikemukakan Zainal Agib (2008:3), "Penelitian Tindakan Kelas adalah suatu penelitian yang dilakukan oleh guru di kelasnya sendiri melalui refleksi dir dengan tujuan untuk memperbaiki kinerjanya sehingga hasil belajar siswa meningkat."

Beberapa alasan mengapa guru dianggap paling tepat untuk melakukan PTK menurut Agib (2008:4) karena : 1) guru mempunyai otonomi untuk menilai kinerjanya, 2) temuan penelitian bisa/formal sering sukar diterapkan untuk memperbaiki pembelajaran, 3) guru merupakan orang yang paling akrab dengan kelasnya, 4) interaksi guru-siswa berlangsung secara unik, dan 5) keterlibatan guru dalam berbagai inovatif yang bersifat pengembangan mempersyaratkan guru mampu melakukan penelitian di kelasnya.

Subyek penelitian ini adalah seluruh siswa kelas VII I SMP Negeri 2 Toroh, Kabupaten Grobogan tahun pelajaran 2015/2016. Penelitian ini dilakukan di SMP Negeri 2 Toroh, J1. Raya Depok No. 61, Kecamatan Toroh, Kabupaten Grobogan.

Observasi dilakukan sebelum penelitian untuk mengungkap masalah-masalah yang muncul dalam pembelajaran IPA (Biologi) di SMP Negeri 2 Toroh sebelum dikenai action researh. Observasi dilakukan selama penelitian untuk mengungkap data yang digunakan dalam penelitian. Penelitian dilakukan pada semester genap tahun pelajaran 2015/2016. Jangka waktu penelitian 4 bulan (Februari 2016 sampai dengan Mei 2016).

Tekanan dalam penelitian ini adalah pada proses pembelajaran untuk meningkatkan ketuntasan belajar siswa. Oleh karena itu faktor-faktor yang dikaji dalam penelitian ini adalah sebagai berikut.

\section{Faktor siswa}

Pengamatan aktivitas siswa dalam proses pembelajaran. Dimana aktivitas siswa dalam proses pembelajaran merupakan indikasi keberhasilan pembelajaran. Selain itu indikasi yang lain dapat dilihat dari hasil belajar yang dicapai siswa.

2. Faktor guru

Faktor guru adalah kemampuan dan ketrampilan guru dalam memilih dan mengembangkan kegiatan pembelajaran melalui kooperatif tipe Two Stay Two Stray (dua tinggal dua tamu) 
untuk meningkatkan penguasaan konsep IPA (Biologi).

Prosedur penelitian yaitu persiapan, perencanaan, pelaksanaan tindakan, pengamatan, dan refleksi-evaluasi.

1. Persiapan

a. Melakukan observasi awal terhadap pembelajaran Biologi di Kelas VII I SMP Negeri 2 Toroh dengan teknik pengamatan.

b. Peneliti bekerja sama menetapkan tindakan yang akan dilakukan untuk mengatasi masalah pembelajaran yang dihadapi.

\section{Perencanaan}

Pada tahap perencanaan, peneliti bersama-sama guru observer menyusun perangkat untuk pelaksanaan proses pembelajaran yang telah ditentukan. Perangkat tersebut adalah sebagai berikut.
a. Rencana Pelaksanaan Pembelajaran (RPP)
b. Lembar Kegiatan Siswa (LKS) dan alat evaluasi
c. Lembar observasi

3. Pelaksanaan Tindakan

Guru melaksanakan kegiatan pembelajaran seperti yang telah direncanakan.

4. Pengamatan

Pada saat guru melaksanakan kegiatan pembelajaran, observasi dilakukan oleh peneliti dan guru observer.

\section{Evaluasi-Refleksi}

Berdasarkan hasil observasi kegiatan pembelajaran yang telah diterapkan, peneliti bersama guru observer melakukan evaluasi. Hasil temuan yang mungkin masih belum maksimal dilakukan, perlu mendapat perhatian untuk pertemuan selanjutnya. Hasil evaluasirefleksi terhadap tindakan yang diterapkan dijadikan bahan pertimbangan untuk menyusun RPP dan LKS agar pelaksanaan siklus pembelajaran berikutnya lebih baik.

Penelitian ini merupakan penelitian tindakan kelas yang dilaksanakan secara bersiklus. Setiap siklus terdiri dari 2-4 kali tatap muka. Setiap siklus terdiri dari 4 tahapan, yaitu perencanaan, pelaksanaan tindakan, observasi, evaluasi dan refleksi. Jika pada pelaksanaan siklus I belum diperoleh hasil sebagaimana indikator keberhasilan, maka tindakan diperbaiki pada siklus selanjutnya, demikian seterusnya.

Penelitian ini menggunakan data berupa dokumen guru model (peneliti), dokumen observer, dokumen siswa, dan foto. Sumber data dalam penelitian ini adalah guru model, guru observer, dokumen siswa.

Alat pengumpulan data menggunakan instrument pembelajaran, (satuan pelajaran), instrumen evaluasi (tes uraian yang berjumlah 5 atau 10 butir soal yang memuat konsep ciri-ciri makhluk hidup dan organisasi kehidupan), instrumen observasi (skala penilaian yang akan diisi oleh pengamat pada saat peneliti mengadakan proses pembelajaran yang berhubungan dengan perilaku mengajar dan aktivitas belajar siswa, dan data refleksi guru dan siswa diambil dengan cara pemberian angket kepada siswa dan guru setelah selesai tiap 
siklus. Teknik pengumpulan data berupa teknik tes dan teknik non tes.

Teknik analisis data dilakukan secara deskriptif kualitatif. Analisis deskriptif digunakan untuk mendeskripsikan implementasi model pembelajaran IPA (biologi) yang dilakukan guru dan untuk menghitung persentase jumlah siswa yang berhasil dalam pembelajaran tersebut. Hal-hal yang dianalisis adalah penampilan mengajar guru dan aktivitas siswa dalam proses pembelajaran.

Analisis data untuk setiap siklus (I dan II) dilakukan secara kualitatif dengan menggunakan model interaktif, yaitu pengecekan data dan informasi dari sumber lain yang dianggap relevan (sesuai), sehingga tingkat keabsahan, keakuratan dan ketepatan data dapat dipertanggungjawabkan.

Indikator keberhasilan dalam penelitian ini adalah apabila guru mampu menerapkan pembelajaran kooperatif tipe Two Stay Two Stray (dua tinggal dua tamu) untuk menciptakan pembelajaran aktif di kelas VII I sehingga terjadi peningkatan hail belajar konsep IPA(Biologi). Adapun indikator keberhasilan dalam penelitian ini adalah hasil belajar IPA (Biologi) $\geq 73$, ketuntasan klasikal $\geq 75 \%$ dari jumlah siswa dalam kelas tersebut, serta aktivitas kelompok meningkat.

\section{HASIL DAN PEMBAHASAN}

Sekolah Menengah Pertama Negeri 2 Toroh merupakan suatu sekolah yang letaknya sangat strategis, berada di pinggir jalan arah Purwodadi - Solo, tepatnya di Jalan Raya Depok No. 61, Kecamatan Toroh, Rata-rata siswa SMP Negeri 2 Toroh berasal dari daerah sekitarnya. SMP Negeri 2 Toroh merupakan sekolah yang berada di pinggiran kota, sehingga siswanya pun memiliki ciri antara anak kota dan desa. Cukup sulit mengendalikan siswa dalam pembelajaran jika pembelajaran yang dilakukan tidak cukup menarik dan menggunakan metode yang monoton, yaitu metode ceramah. Hingga saat ini metode ini dianggap sebagai metode yang dianggap paling ampuh untuk membantu siswa dalam memperoleh pengetahuan. Pada beberapa waktu terakhir ini terdapat beberapa keluhan guru terhadap hasil belajar siswanya, tak terkecuali pula bagi siswa kelas VII I tahun pelajaran 2015/2016.

Sebelum pelaksanaan tindakan kelas, guru menyampaikan materi mengenai mikroskop dengan metode seperti biasa, yaitu ceramah disertai dengan diskusi kelompok besar berupa team quiz. Materi yang dipelajari pada tahap prasiklus ini tentang mikroskop. Kegiatan Belajar Mengajar (KBM) diawali dengan apersepsi mengenai bentuk mikroskop dan bagaimana cara menggunakannya sesuai dengan informasi yang diketahui siswa. Kemudian guru memberikan penjelasan mengenai bagian-bagian dan fungsi mikroskop serta cara menggunakan mikroskop. Guru juga memberi penjelasan mengenai cara membuat preparat basah dari bawang merah. Guru memberikan penjelasan dengan metode ceramah dengan antusias. Namun ada beberapa siswa yang tidak memperhatikan penjelasan guru. Selesai menjelaskan cara membuat preparat basah dari bawang merah, kemudian guru membagi siswa menjadi tiga kelompok secara acak. Pembelajaran selanjutnya menggunakan team quiz.

Berdasarkan kasus dengan menggunakan kooperatif tipe team quiz pada observasi awal sebelum dilakukan penelitian, aktivitas siswa kurang, siswa dalam satu kelompok lebih mengandalkan teman yang pandai untuk menghidupkan pembelajaran. Berdasar evaluasi yang dilakukan ternyata hasil belajar siswa kelas VII I pada semester dua awal 
kurang memuaskan dan ketuntasan hasil belajar klasikal masih kurang (hanya 41,2 \% siswa memiliki nilai $\geq 73$ ). Kegiatan dengan menggunakan kooperatif tipe team quiz terdiri dari tiga kelompok untuk 34 siswa, sehingga tiap kelompok memiliki anggota antara 11 hingga 12 anak ternyata tidak dapat membuat anak lebih aktif. Pembelajaran yang dilakukan memang cenderung menggunakan ceramah, sehingga cukup banyak siswa yang merasa bosan atau mengantuk. Jikalau menggunakan sistem kelompok, jumlah anggota kelompok pun terlalu banyak sehingga masih terdapat banyak siswa yang hanya bergantung pada teman yang pandai. Hanya beberapa siswa saja yang bisa berkonsentrasi untuk melaksanakan kegiatan pembelajaran. Tentu saja hal ini berpengaruh terhadap hasil belajar siswa.

\section{Deskripsi Hasil Siklus I}

Tujuan utama dari penelitian ini adalah untuk mengikuti adanya peningkatan ketuntasan belajar IPA siswa kelas VII I SMP Negeri 2 Toroh pada semester genap tahun pelajaran 2015/2016. Siklus I dilaksanakan melalui dua kali pertemuan. Pertemuan pertama menerapkan pembelajaran kooperatif tipe Two Stay Two Stray (dua tinggal dua tamu) dan pertemuan yang kedua digunakan untuk evaluasi dan pembahasan hasil evaluasi siswa. Materi pada Siklus I mengenai ciri-ciri makhluk hidup, kompetensi dasarnya adalah mengidentifikasi ciri-ciri makhluk hidup. Rangkaian kegiatan yang dilaksanakan pada Siklus I adalah sebagai berikut.

1. Perencanaan

Beberapa hal yang dilakukan sebelum pelaksanaan pembelajaran adalah sebagai berikut.

a. Menyusun rencana pembelajaran pada materi ciri-ciri makhluk hidup.

b. Merencanakan pembelajaran dengan membentuk kelompok dengan anggota pada tiap kelompok sebanyak empat siswa dengan penyebaran tingkat kecerdasan secara acak. Pembentukan delapan kelompok dengan cara siswa memilih sendiri teman satu kelompok.

c. Menyusun materi/soal.

d. Merencanakan tempat duduk pada tiap kelompok.

\section{Pelaksanaan Tindakan}

Tindakan guru dalam pelaksanaan tindakan Siklus I sesuai dengan prosedur perencanaan adalah sebagai berikut.

a. Guru membagi siswa dalam bentuk kelompok-kelompok kecil dengan jumlah anggota pada tiap kelompok sebanyak empat ( kecuali dua kelompok yang terdiri dari lima siswa karena jumlah siswa 34 dalam satu kelas) siswa dengan tingkat kecerdasan secara acak. Pembagian anggota kelompok tanpa memperhatikan penyebaran kecerdasan siswa.

b. Guru memberikan pertanyaan singkat dan simpulan singkat di kelas sebagai motivasi.

c. Guru membagi lembar kerja siswa untuk tiap kelompok.

d. Guru meminta siswa untuk mengerjakan soal pada lembar kerja siswa secara diskusi. Jawaban ditulis di kertas rangkap delapan sesuai jumlah kelompok yang terbentuk.

e. Guru meminta dua siswa sebagai tamu dan dua siswa lainnya tetap tinggal dikelompoknya untuk masing-masing kelompok. 
f. Guru memberikan arahan pada siswa yang berperan sebagai tamu untuk bertamu pada kelompok lainnya secara menyeluruh. Dua siswa yang berperan sebagai tamu mengambil lembar kerja siswa kelompok lain yang mereka datangi. Dua siswa yang berperan sebagai tamu membaca sekilas pekerjaan kelompok yang mereka datangi dan menanyakan jawaban yang sekiranya belum mereka pahami maksudnya pada dua siswa yang tinggal tersebut. Dua siswa yang tetap tinggal sebagai tuan rumah memberikan penjelasan pada siswa yang berperan sebagai tamu atas pertanyaan yang dilontarkan siswa tamu. Waktu yang diberikan untuk mengambil lembar kerja sekaligus menggali informasi dari kelompok lain adalah lima menit.

g. Guru meminta siswa tamu untuk kembali ke kelompoknya masing-masing setelah siswa tamu selesai melaksanakan tugas bertamu.

h. Guru meminta siswa pada tiap kelompok untuk mendiskusikan jawaban dari kelompok lain dengan jawaban dari kelompoknya.

i. Guru dan siswa membahas soal pada lembar kerja pada diskusi kelas. Guru meminta perwakilan kelompok mengemukakan jawaban mereka sesuai instruksi guru dan ditanggapi oleh kelompok lain dan dibuat jawaban bersama.

j. Guru meminta siswa membuat kesimpulan dengan arahan dari guru.

3. Observasi (pengamatan)

Pembelajaran kooperatif tipe Two Stay Two Stray (dua tinggal dua tamu) dilaksanakan di ruang kelas VII I. Siswa memasuki ruangan dan langsung menempati tempat duduk sesuai kelompoknya masing-masing berdasarkan pembagian kelompok yang sudah ditentukan sebelumnya.

Pada awal pembelajaran, guru memberikan apersepsi dengan meminta siswa untuk memperhatikan benda-benda yang berada di sekitar lingkungan sekolah. Kemudian guru menanyakan pada siswa, manakah yang merupakan benda hidup dan manakah yang merupakan benda mati. Beberapa anak menjawab dengan benar. Guru memberikan sedikit penjelasan bahwa benda hidup/ makhluk hidup memiliki ciri-ciri makhluk hidup, sedangkan benda mati tidak memiliki ciri-ciri makhluk hidup secara menyeluruh seperti pada makhluk hidup. Kemudian guru meminta satu perwakilan dari kelompok untuk mengambil lembar kerja yang harus dikerjakan secara berkelompok. Guru memberikan penjelasan supaya tiap kelompok menuliskan jawaban sebanyak delapan kali yang nantinya satu lembar jawab itu tetap dibawa masing-masing kelompok, sedangkan tujuh lembar jawab lainnya diberikan pada kelompok lain. Guru meminta siswa untuk membagi penulisan jawaban sebanyak delapan kali tersebut sehingga bisa menyelesaikan diskusi kelompok sekaligus menuliskannya tepat waktu dari waktu yang ditentukan oleh guru yaitu 40 menit.

Selesai pembagian tersebut, siswa mulai asyik untuk mencari jawaban soal pada LKS dan buku Science (terbitan Erlangga) yang dimiliki masing-masing siswa, maupun dari buku yang di pinjam dari sekolah, baik buku terbitan Yudhistira maupun BSE. Sebagian siswa cenderung untuk mencari jawaban pada LKS, hanya beberapa siswa saja yang memadukan informasi dari keempat buku sumber yang ada. Masih terdapat beberapa siswa yang tidak langsung mencari jawaban, mereka justru bercerita dengan temannya atau mencari kesibukan sendiri yang tidak berhubungan tugas yang seharusnya mereka kerjakan. Mereka kemudian 
menuliskan jawaban sebanyak beberapa kali sesuai dengan bagian yang telah ditentukan dalam kelompoknya. Guru melihat siswa yang melakukan kegiatan tersebut. Guru meminta siswa untuk mencari jawaban soal secara diskusi, bukan justru menyerahkan tugas menjawab bagi teman tertentu saja. Siswa tersebut akhirnya mau melihat soal dan mencoba mencari. Namun saat guru memperhatikan kelompok lain sehingga tidak melihat ke siswa tersebut, maka siswa itu akan melakukannya lagi. Guru menegur siswa tersebut hingga dua kali. Hanya beberapa siswa yang memanfaatkan waktu untuk melakukan aktivitas positif, sebagian kecil tetap bercerita atau bahkan bercanda dengan temannya. Namun hanya sebentar saja karena guru meminta siswa lebih serius untuk segera menyelesaikan tugasnya.

Sesuai waktu yang telah diberikan, maka selanjutnya guru meminta perhatian siswa kembali. Guru memberikan penjelasan mengenai kegiatan berikutnya, yaitu meminta dua orang siswa berperan sebagai tamu dan dua lainnya tetap berada dikelompoknya dengan membawa lembar jawab yang sudah ditulis sebanyak delapan kali. Guru meminta masingmasing kelompok menyimpan satu lembar jawabnya untuk nantinya didiskusikan kembali pada saat siswa yang berperan sebagai tamu kembali ke kelompoknya masing-masing dengan membawa jawaban dari kelompok lain.

Guru menjelaskan cara bertamu pada kelompok lain supaya dua siswa yang tetap tinggal di kelompoknya tidak kebingungan menghadapi tamu yang lebih dari satu, sedangkan ada kelompok lain yang hanya diam menunggu tamu datang. Guru memberikan contoh untuk dua tamu bertamu/mengambil lembar jawab pada kelompok mana. Tugas dua tinggal adalah memberikan lembar jawabnya dan memberikan penjelasan atas pertanyaan dari tamu. Waktu yang diberikan untuk tiap perpindahan adalah dua menit. Guru memberi tanda untuk berpindah dengan menggunakan ketukan dua kali. Pada gerakan yang pertama, siswa yang berperan sebagai dua tamu dapat berpindah pada kelompok lain dengan baik. Namun mulai pada yang perpindahan kedua, siswa mulai bingung untuk bertamu pada kelompok mana lagi. Meski sempat mengalami kebingungan, namun siswa yang berperan sebagai tamu akhirnya dapat menentukan kelompok mana yang harus didatangi. Sebagian besar dua tamu dari tiap kelompok tidak mendengarkan maupun membaca jawaban kelompok yang dikunjungi, namun hanya mengambil jawaban saja. Dua tamu dalam beberapa kelompok justru memperhatikan siswa lain, padahal seharusnya dia memperhatikan penjelasan dari dua tinggal. Setelah siswa yang berperan sebagai tamu kembali ke kelompoknya masing-masing, guru meminta masing-masing kelompok untuk mendiskusikan jawaban kelompok lain dengan jawaban dari kelompoknya. Kemudian siswa mempresentasikan hasil diskusi. Keseluruhan pembelajaran keaktifan siswa lebih baik disbanding dengan prasiklus. Berdasarkan hasil evaluasi Siklus I masih terdapat siswa yang belum tuntas yaitu memiliki nilai yang kurang dari 73 sebanyak tujuh siswa dari 34 siswa. Prosentase ketuntasan belajar siswa pada Siklus I adalah 79,4 \% dan prosentase ketidaktuntasannya adalah 20,6\%. Nilai rata-rata siswa kelas VII I adalah 75,82 .

\section{Evaluasi dan Refleksi}

Berdasarkan observasi pada saat perlakuan menggunakan kooperatif tipe Two Stay Two Stray (dua tinggal dua tamu), terdapat beberapa hal perlu diperbaiki yaitu manajemen waktu. Jumlah soal dan penjabaran jawaban soal perlu dikurangi disesuaikan dengan waktu yang ada. 
Guru perlu lebih aktif memotivasi siswa saat kegiatan diskusi kelompok dan tidak segan-segan memberikan punishment jika memang diperlukan. Guru lebih disiplin dalam memberikan waktu pada siswa umtuk melakukan tugasnya, tidak perlu diberi waktu tambahan. Anggota kelompok perlu diganti supaya penyebaran kecerdasan di tiap kelompok lebih merata.

\section{Deskripsi Hasil Siklus II}

Siklus II dilaksanakan sebanyak empat kali pertemuan. Pertemuan pertama hingga ketiga menerapkan pembelajaran kooperatif tipe Two Stay Two Stray (dua tinggal dua tamu) dan pertemuan keempat digunakan untuk evaluasi dan pembahasan hasil evaluasi siswa. Materi pada Siklus II mengenai organisasi kehidupan, kompetensi dasarnya adalah mendeskripsikan keanekaragaman pada sistem organisasi kehidupan mulai dari tingkat sel sampai organisme. Rangkaian kegiatan yang dilaksanakan pada Siklus II sama seperti pada kegiatan pada Siklus I yang berbeda hanya pengaturan waktu dan anggota ditiap kelompok yang diatur oleh guru peneliti.

Pelaksanaan pembelajaran kooperatif tipe Two Stay Two Stray (dua tinggal dua tamu) pada Siklus II lebih baik dari Siklus I. Secara umum. Aktivitas siswa dalam proses pembelajaran pada Siklus II lebih baik dari Siklus I. Pada Siklus II siswa sudah jauh lebih memahami teknis pelaksanaan pembelajaran materi Organisasi Kehidupan menggunakan tipe dua tinggal dua tamu, meski ada beberapa perbedaan secara teknis dalam pelaksanaan pembelajaran antara Siklus I dengan Siklus II. Siswa lebih serius dalam mengerjakan soal maupun dalam diskusi dan penyampaian hasil diskusi. Keaktifan siswa lebih tinggi pada pada kategori keempat (kategori sangat baik) sebesar 53\%.

Pada Siklus II siswa sudah mampu melakukan perpindahan ke kelompok lain dengan lancar. Pelaksanaan diskusi untuk mengerjakan soal sudah baik, siswa lebih cepat mencari jawaban dan menulis. Masih terdapat siswa yang belum mau membantu temannya dalam menjawab pertanyaan pada pertemuan pertama dan kedua, yaitu dua siswa laki-laki dari kelompok 4. Bahkan ada yang melihat ke luar kelas karena ruang kelas dekat jalan raya. Ruang kelas yang dekat jalan raya membuat siswa bisa melihat banyak kendaraan yang melaju lalu lalang.

Berdasarkan hasil evaluasi Siklus II masih terdapat siswa yang belum tuntas yaitu memiliki nilai yang kurang dari 73 sebanyak delapan siswa dari 34 siswa. Prosentase ketuntasan belajar siswa pada Siklus I adalah 76,4 \% dan prosentase ketidaktuntasannya adalah 23,6\%. Nilai rata-rata siswa kelas VII I adalah 75,82. Berikut ini merupakan grafik ketuntasan belajar siswa pada Siklus II.

\section{PEMBAHASAN}

Pembahasan Pelaksanaan Tindakan Prasiklus, Siklus I dan Siklus II. 
PROSENTASE KETUNTASAN BELAJAR PRASIKLUS, SIKLUS I, DAN SIKLUS II

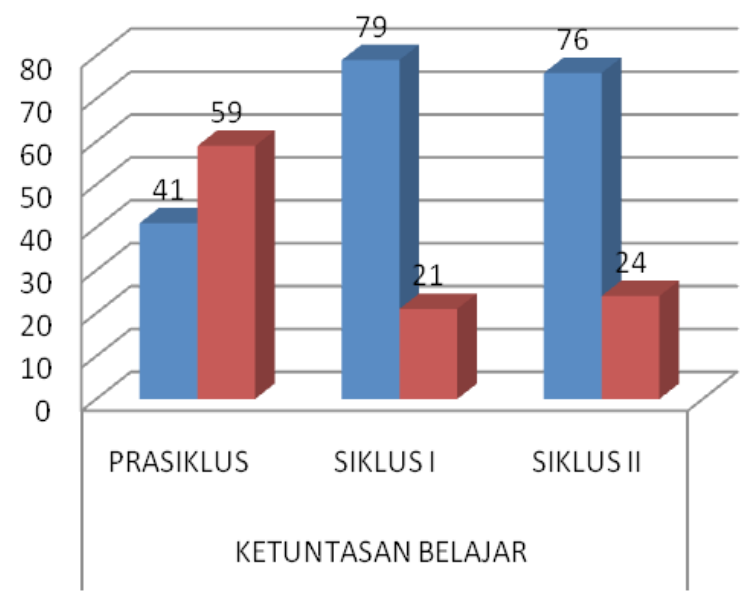

\% ketuntasan

m ketidaktuntasan

Nilai rata-rata siswa setelah diberi perlakuan dengan pembelajaran TSTS juga mengalami peningkatan, baik pada Siklus I maupun Siklus II, yaitu dari 66,32 saat tahap prasiklus menjadi 75,82 pada Siklus I, dan 72,91 pada Siklus II. Berikut merupakan tabel rata-rata nilai siswa kelas VII I.

Tabel 1 Rata-rata Nilai Siswa Kelas VII I pada Tahap Prasiklus, Siklus I, dan Siklus II

\begin{tabular}{ccc}
\hline \multicolumn{3}{c}{ NILAI RATA-RATA SISWA } \\
\hline Prasiklus & Siklus I & Siklus II \\
66,32 & 75,82 & 72,91 \\
\hline
\end{tabular}

Pembelajaran kooperatif tipe Two Stay Two Stray (dua tinggal dua tamu) juga mampu menaikkan keaktifan siswa. Siswa lebih aktif dalam melakukan pembelajaran pada Siklus II daripada tahap prasiklus dan Siklus I, dari $30 \%$ siswa yang aktif pada tahap prasiklus menjadi $>30 \%$ pada tahap Siklus I dan Siklus II. Kenaikan keaktifan siswa dalam proses pembelajaran pada Siklus I prosentase keaktifan siswa paling tinggi pada kategori tiga (kategori baik) sebesar 44\%, sedangkan pada Siklus II prosentase keaktifan paling tinggi pada kategori keempat (kategori sangat baik) sebesar 53\%.

Pembelajaran kooperatif dengan model Two Stay Two Stray (TSTS) atau model dua tinggal dua tamu merupakan salah satu model pembelajaran secara diskusi kelompok yang membuat siswa harus bekerja sama dengan siswa lain dalam satu kelompok maupun dengan kelompok lain. Dalam model ini terdapat empat siswa dalam satu kelompok yang terbagi menjadi dua bagian, yaitu dua siswa yang berperan sebagai tuan rumah dan dua orang yang berperan sebagai tamu. Setiap kelompok tidak hanya menuliskan satu hasil diskusi, melainkan harus membuat beberapa salinannya untuk dibagikan pada kelompok lain. Dengan membuat beberapa salinan jawaban hasil diskusi, - setiap siswa menuliskan satu kali atau dua kali jawaban hasil diskusi - maka siswa akan lebih paham dan dapat mengingat materi 
yang telah didiskusikan bersama. Pada pembelajaran kooperatif dengan model Two Stay Two Stray (TSTS) atau model dua tinggal dua tamu ini siswa selain membuat beberapa salinan hasil diskusi, mereka juga harus membacakan pada kelompok lain secara bergiliran dan satu perwakilan kelompok harus mempresentasikan hasil diskusi. Dengan demikian, maka siswa akan lebih matang dalam memahami materi. Pembelajaran kooperatif dengan model Two Stay Two Stray (TSTS) atau model dua tinggal dua tamu merupakan model pembelajaran yang jarang digunakan dalam pembelajaran di sekolah, namun demikian pembelajaran dengan tipe ini merupakan salah satu model pembelajaran yang efektif untuk meningkatkan hasil belajar siswa.

\section{PENUTUP}

Berdasarkan hasil observasi awal di SMP N 2 Toroh, diketahui bahwa nilai rata-rata siswa kelas VII I adalah 66,32 dan ketuntasan belajar siswa siswa adalah 41,2\%. Ketuntasan belajar yang rendah ini disebabkan oleh metode pembelajaran yang diterapkan masih menggunakan metode ceramah, diskusi kelompok besar, dan tanya jawab. Metode-metode ini membentuk siswa pasif dan tidak memberikan cukup ruang bagi siswa untuk berkreativitas. Siswa juga kurang bersemangat dalam mengikuti proses pembelajaran. Pada saat proses belajar mengajar siswa tampak bosan, mengantuk, sering tidak memperhatikan penjelasan guru, dan siswa cenderung santai dalam diskusi kelompok karena kurangnya tanggung jawab individu yang dimilikinya.

Berdasarkan hasil penelitian tindakan kelas yang dilakukan dengan dua siklus dengan menggunakan pembelajaran kooperatif tipe Two Stay Two Stray (dua tinggal dua tamu) diperoleh kesimpulan bahwa temuan pada Siklus I dan Siklus II adalah terjadi peningkatan hasil belajar siswa, yaitu nilai rata-rata kelas dari 66,32 menjadi 75,82 pada Siklus I, dan 72,91. Tipe TSTS juga mampu meningkatkan ketuntasan belajar siswa jika dibandingkan dengan tahap prasiklus. Ketuntasan belajar siswa kela VII pada tahap prasiklus adalah $41,2 \%$, naik menjadi 79,4 \% pada Siklus I dan 76,4 \% pada Siklus II. Berdasarkan indikator keberhasilan penelitian ini, ketuntasan belajar Siklus I maupun siklus II dikatakan berhasil karena $\geq 75 \%$ yaitu 79,4 \% dan 76,4 \%. Meskipun dari siklus I ke siklus II terjadi penurunan nilai rata-rata kelas maupun ketuntasan belajar belajar siswa, namun pembelajaran IPA dengan tipe dua tinggal dua tamu dikatakan berhasil karena terjadi peningkatan jika dibandingkan dengan tahap prasiklus.

Aktifitas belajar siswa juga mengalami kenaikan dalam proses pembelajaran kooperatif tipe Two Stay Two Stray (dua tinggal dua tamu). Pada Siklus I prosentase keaktifan siswa paling tinggi pada kategori tiga (kategori baik) sebesar 44\%, sedangkan pada Siklus II prosentase keaktifan paling tinggi pada kategori keempat (kategori sangat baik) sebesar 53\%.

Proses pembelajaran tampak lebih aktif saat menggunakan pembelajaran kooperatif tipe Two Stay Two Stray (dua tinggal dua tamu). Siswa lebih banyak melakukan kegiatan pembelajaran daripada bermain sendiri maupun bercanda dengan temannya. Siswa tidak merasa mengantuk karena kasibukan yang mereka lakukan untuk mencapai keberhasilan kerja sama kelompok. Siswa lebih diberi kesempatan untuk mengungkapkan pemikiran yang mereka miliki maupun mendengarkan pendapat temannya. 


\section{DAFTAR PUSTAKA}

Arikunto, Suharsimi. 1993. Manajemen Pengajaran Secara Manusiawi. Jakarta: PT. Rineka Cipta.

Azhar, Ahmad, dkk. 2008. Penerapan Pembelajaran Kooperatif Model Dua Tinggal Dua Tamu untuk Meningkatkan Proses dan Hasil Belajar Fisika Siswa Kelas X-1. Skripsi: FMIPA Universitas Negeri Malang. http://karya-ilmiah.um.ac.id/indexphp/pkm/ article/2106. Diakses tanggal 8 Januari 2010.

Dimyati, dkk. 2002. Belajar dan Pembelajaran. Jakarta: Rineka Cipta.

Nasution. 2000. Didaktik Azas-azas Mengajar. Jakarta: Bumi Aksara.

Nuryani. 2005. Strategi Belajar Mengajar IPA. Malang: Universitas Negeri Malang Press.

Prasodjo, Budi, dkk. 2007. IPA Terpadu 1B. Yudhistira.

Priambodo, Bambang A., dkk. 2009. Science for Junior High School Grade VII $2^{\text {nd }}$ Semester. Jakarta:Erlangga.

Sagala, Syaiful. 2006. Konsep dan Makna Pembelajaran. Bandung: CV. Alfabeta.

Sanjaya, Wina. 2008. Strategi Pembelajaran. Jakarta:Kencana.

Slameto. 2003. Belajar dan Faktor-faktor yang Mempengaruhinya. Jakarta: PT. Rineka Cipta.

Soedijarto. 1993. Memantapkan Sistem Pendidikan Nasional. Jakarta: Gramedia.

Sularyo. 2004. Upaya Meningkatkan Ketuntasan Belajar IPA yang Berwawasan SETS dengan Metode Belajar Kelompok Pada Siswa Kelas II SMU Negeri 2 Semarang Tahun 2002 - 2003. Tesis: PPS Unnes

Sutama. 2011. Penelitian Tindakan (Teori dan Praktek dalam PTK, PTS, dan PTBK). Semarang:CV. Citra Mandiri Utama.

Tim Khusus KTSP SMP N 2 Toroh. 2015. KTSP SMP N 2 Toroh 2015/2016. Grobogan : SMP N 2 Toroh.

Tung, Khoe Yao. 2015. Pembelajaran dan Perkembangan Belajar. Jakarta:Indeks.

Uno, Hamzah B. 2006. Model Pembelajaran Menciptakan Proses Belajar Mengajar yang Kreatif dan Efektif. Jakarta: Bumi Aksara.

Zainal Agib. 2008. Penelitian Tindakan Kelas untuk Guru SMP, SMA, SMK. Bandung: CV. Yrama Widya. 